\title{
QUANTIFICATION OF Salmonella Typhimurium REDUCTION DURING COLD STORAGE OF RAW SHRIMPS IN THE PRESENCE OF SODIUM METABISULFITE
}

\author{
[Kuantifikasi Reduksi Salmonella Typhimurium pada Udang Segar selama Penyimpanan Dingin dengan \\ Penambahan Natrium Metabisulfit]
}

\author{
Harsi Dewantari Kusumaningrum ${ }^{1,2)^{*}}$ and Andiarto Yanuardi ${ }^{3)}$ \\ 1) Department of Food Science and Technology, Faculty of Agricultural Engineering and Technology, \\ Bogor Agricultural University, Bogor \\ 2) Southeast Asian Food Agricultural Science and Technology (SEAFAST) Center, Bogor Agricultural University, Bogor \\ 3) Food Science Study Program, Bogor Agricultural University, Bogor
}

Submitted November $13^{\text {th }} 2012$ / Accepted December $13^{\text {th }} 2012$

\begin{abstract}
Prediction of bacterial growth, survival or reduction in food matrices is needed for microbiological risk assessment. The survival of Salmonella Typhimurium on surfaces of raw shrimps at low temperature was studied, in the presence of sodium metabisulfite which is often used to prevent melanosis. The growth and/or reduction rates were quantified using DMFit software with Baranyi model and or linear model. The result showed that without sodium metabisulfite (control), when the initial level was high ( $\left.10^{5} \mathrm{CFU} / \mathrm{ml}\right)$, S. Typhimurium grew with a lag phase of $51.99 \pm 7.46 \mathrm{~h}$ and a growth rate of $0.01 \pm 0.002 \mathrm{log} C F U . \mathrm{ml}^{-1} \cdot \mathrm{h}^{-1}$ on raw shrimps during storage at $8 \pm 2^{\circ} \mathrm{C}$. When $1.5 \%(\mathrm{w} / \mathrm{w})$ sodium metabisulfite, a maximum level that often used to prevent melanosis, was added under the same condition, the number of $S$. Typhimurium was reduced for $5 \mathrm{log} C F U / \mathrm{ml}$ after 5 days, with a reduction rate of $-0.03 \pm 0.001 \log \mathrm{CFU} \cdot \mathrm{ml}^{-1} . \mathrm{h}^{-1}$. This study indicated that Baranyi model can be used to predict the growth of $S$. Typhimurium on raw shrimp at low temperature, when sodium metabisulfite is absent. However, when sodium metabisulfite is present, at least $0.4 \%$ as found in this study, the reduction of $S$. Typhimurium can be predicted using a simple linear model.
\end{abstract}

Keywords: Baranyi model, DMFit, raw shrimp, Salmonella, sodium metabisulfite

\begin{abstract}
ABSTRAK
Pendugaan pertumbuhan, ketahanan atau reduksi bakteri pada matriks pangan diperlukan dalam kajian risiko mikrobiologi. Pada penelitian ini dikaji ketahanan Salmonella Typhimurium pada permukaan udang selama penyimpanan suhu rendah dengan penambahan natrium metabisulfit yang sering digunakan untuk mencegah melanosis pada udang beku. Laju pertumbuhan dan/atau reduksi yang diperoleh diolah menggunakan software DMFit dengan model Baranyi. Hasil penelitian menunjukkan bahwa dengan jumlah awal yang tinggi $\left(10^{5} \mathrm{CFU} / \mathrm{ml}\right)$ pada suhu $8 \pm 2^{\circ} \mathrm{C}$,

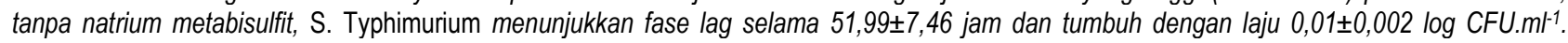
$h^{-1}$ pada udang mentah. Dengan konsentrasi 1,5\%, tingkat maksimum yang sering digunakan untuk mencegah melanosis, natrium metabisulfit mampu mereduksi jumlah S. Typhimurium sebanyak $5 \mathrm{log}$ CFU/ml setelah 5 hari pada kondisi yang sama dengan laju reduksi $-0,03 \pm 0,001$ log CFU.ml-1. $h^{-1}$. Studi ini menunjukkan bahwa model Baranyi dapat digunakan untuk memprediksi pertumbuhan S. Typhimurium pada suhu rendah pada udang mentah, jika tidak terdapat natrium metabisulfit. Namun, jika terdapat natrium metabisulfit, setidaknya 0,4\% seperti yang digunakan dalam penelitian ini, reduksi S. Typhimurium dapat diprediksi menggunakan model linier.
\end{abstract}

Kata kunci: DMFit, model Baranyi, udang mentah, Salmonella, sodium metabisulfit

\section{INTRODUCTION}

Salmonella contamination has been noted as important causal of shrimp import detention by FDA, and found in retail markets in some countries, such as India, Malaysia, Vietnam, Japan and Indonesia (Wan Norhana et al., 2010). Prediction of bacterial survival in food matrices, e.g. shrimp, is therefore important for conducting microbiological risk assessment to

Paper was Presented at International Conference on "Future of Food Factors", October 3-4, 2012, Jakarta, Indonesia.

*Corresponding Author:

E-mail : harsikusumaningrum@yahoo.com control the safety of the product. Prediction can be modeled with Baranyi, a popular model in recent time (Sant'Ana et al., 2012) incorporated with DMFit software.

Furthermore, the growth or survival of Salmonella in food can be affected by various factors including temperature, $\mathrm{pH}$, water activity, preservatives and particular treatments. In shrimp processing plants, sodium metabisulfite is often used to prevent the process of melanosis on shrimp (Martinez-Alvarez et al., 2009). Melanosis or blackening is induced by polyphenol oxidase that oxidized phenols to from colourless quinones. These quinones can undergo further oxidation to from brown melanin (Nirmal and Benjakul, 2011). Melanosis has no impact on the flavour of shrimp and is not harmful to consumers. 
However, the black spots can drastically affect consumer acceptability of the products and significantly diminish their market value. Additional effect of sodium metabisulfite on the growth of Salmonella, however, is limited known. The main objective of this study was, therefore, to determine the effect of cold storage $\left(8 \pm 2^{\circ} \mathrm{C}\right)$ on the growth of Salmonella Typhimurium on surfaces of raw shrimp with or without the addition of sodium metabisulfite. Quantification of the survival and reduction of Salmonella on raw shrimps were also studied using DMFit software with Baranyi model.

\section{MATERIALS AND METHODS}

\section{Materials}

Peeled undeveined (headless, skinless, and tailless but its intestines were not taken out) frozen white shrimp (Litopenaeus vannamei) from shrimp processing industry were used. The sample had been treated with $1.5 \%$ phosphate and $1.5 \% \mathrm{NaCl}$. Commercial sodium metabisulfite $\left(\mathrm{Na}_{2} \mathrm{~S}_{2} \mathrm{O}_{5}\right)$ was obtained from local supplier. Salmonella Typhimurium ATCC 14028 was used as test organism.

\section{Observation of the growth patterns of $S$. Typhimurium at optimum and low temperatures}

Growth curve of $S$. Typhimurium at $35 \pm 2^{\circ} \mathrm{C}$ in Brain Heart Infusion Broth (BHIB, Difco) was generated to obtain the stationary phase of bacterial growth at optimum condition. Xylose Lysine Desoxycholate agar (XLDA, Oxoid) was used as plating media in duplicates. Therefore, initial colony of $10^{1}$ $\mathrm{CFU} / \mathrm{ml}$ was prepared, inoculated into BHIB and incubated at $35 \pm 2^{\circ} \mathrm{C}$ for 24 hours. The total Salmonella were observed at 0 , $0.5,1,2,4,6,10,14,18,20$, and 24 hours. This procedure was repeated two times.

Growth curve of $S$. Typhimurium was also observed at low temperature $\left(8 \pm 2^{\circ} \mathrm{C}\right)$ for 7 days in $\mathrm{BHIB}$ and shrimps, with initial level of $10^{3} \mathrm{CFU} / \mathrm{ml}$ to $10^{6} \mathrm{CFU} / \mathrm{ml}$. Artificially contamination of shrimps was conducted by dipping a set of shrimps sample (containing 10 pieces) into $S$. Typhimurium suspension (obtained from 24 hours old culture) for 60 seconds, and left for 30 minutes in refrigerator on a polystyrene pack covered with plastic wrap, to allow the attachment of bacteria to the sample before the first sampling. These samples were then stored in the same refrigerator, and sampled everyday up to 7 days. Enumeration of the bacteria was also conducted on XLDA and incubated at $35 \pm 2^{\circ} \mathrm{C}$ for 24 hours. This procedure was repeated two times.

\section{Determination of antimicrobial properties of sodium meta- bisulfite}

The antibacterial properties of sodium metabisulfite was tested against $S$. Typhimurium at optimum temperature using different concentrations (w/v), i.e. $0 \%$ (control), $0.4 \%, 0.5 \%$, $0.6 \%, 0.7 \%, 0.8 \%, 0.9 \%, 1 \%, 1.25 \%$ and $1.5 \%$ in tubes containing $10 \mathrm{ml} \mathrm{BHIB}$. The initial number of bacteria was $10^{5}$ $\mathrm{CFU} / \mathrm{ml}$. The tubes were then incubated at $35 \pm 2^{\circ} \mathrm{C}$ for 24 hours Observations of the antibacterial properties were made after inoculation (t 0 ) and after incubation for 24 hours, by plating to Tryptone Soy Agar (TSA, Oxoid) media and incubated at
$35 \pm 2^{\circ} \mathrm{C}$ for 24 hours. Moreover, the antibacterial properties of sodium metabisulfite against $S$. Typhimurium were also tested in $\mathrm{BHIB}$ at low temperature. Therefore, a set of 4 sterilized test tubes containing $10 \mathrm{ml} \mathrm{BHIB}$, added with sodium metabisulfite with selected concentrations of $0 \%, 0.4 \%, 1.25 \%$ and $1.5 \%$ $(\mathrm{w} / \mathrm{v})$, were inoculated with $S$. Typhimurium (approximately $10^{5}$ $\mathrm{CFU} / \mathrm{ml})$. Test tubes were then stored at low temperatures $8 \pm 2^{\circ} \mathrm{C}$ for 7 days, and sampled everyday up to 7 days on XLDA incubated at $35 \pm 2^{\circ} \mathrm{C}$ for 24 hours.

\section{Survival of $S$. Typhimurium on shrimps at low temperatures with the addition of sodium metabisulfite}

Two set of shrimps samples (containing 10 pieces) were washed with distilled water (water temperature was approximately $4^{\circ} \mathrm{C}$ ) and soaked in sodium metabisulfite solution (shrimp: solution was $1: 2(\mathrm{w} / \mathrm{v})$ ) for $3-5$ minutes. The concentrations of sodium metabisulfite were $0 \%, 0.4 \%, 1.25 \%$, or $1.5 \%$. After draining for 30 seconds, the shrimps were artificially contaminated following procedure described above. A set of shrimps, without treatment of sodium metabisulfite, was also contaminated and tested as control.

Survival of $S$. Typhimurium on raw shrimps at low temperature $\left(8 \pm 2^{\circ} \mathrm{C}\right)$ was observed everyday up to 7 days and enumerated using XLDA agar.

\section{Fitting the growth curves and survival of $S$. Typhimurium under test condition}

The data were plotted in growth and/or survival curves, using Excel program for Windows. Fitting of the growth curve was conducted using DMFit software. DMFit software is an Excel add-in fitting curves software where a linear phase is preceded and followed by stationary phases. Some parameters were generated, i.e. growth rate $(\mu)$, lag phase $(\lambda)$, and $y_{\text {max. }}$. DMFit (Dynamic Modelling) is based on the Baranyi model with the following equation:

$$
y(t)=y_{0}+\mu_{\max } A(t)-\frac{1}{m} \ln \left[1+\frac{e^{m \mu A(t)}-1}{e^{m\left(y_{\max }-y_{0}\right)}}\right]
$$

with $y(t)=\ln x(t), y_{0}=\ln x_{0}$, and $v$ is the average increase of substrate, which is generally assumed to be equal to $\mu_{\max }$ (growth rate), the parameter $m$ characterizing the curve before the stationary phase, $A(t)$ is lag phase, and $y_{\max }$ is the end of the log phase which is $I n x_{\text {max }}$. Moreover, if the survival or reduction of Salmonella were linear, then the calculation can be conducted using linear regression. The general form of the linear equation can be written as follows:

$$
y=a x+b
$$

with: $a=$ slope of straight line curve, $b=$ intersection (intercept) curve with the 'ordinate' or the vertical axis.

\section{Data analysis}

Statistical data analysis was conducted using SPSS 17.0 software and Duncan test. The analyses were done to determine the effect of storage time at low temperatures and the addition of sodium metabisulfite. 


\section{RESULTS AND DISCUSSION}

\section{Growth of S. Typhimurium in Brain Heart Infusion broth (BHIB) and shrimps}

The growth curves of $S$. Typhimurium ATCC 14028 in BHIB, at its optimum growth temperature and at low temperature $\left(8 \pm 2^{\circ} \mathrm{C}\right)$ are shown at Figure 1. At optimum temperature $\left(35 \pm 2^{\circ} \mathrm{C}\right)$, the stationaire phase was reached after 6 to 8 hours, with a growth rate $(\mu)$ of $1.73 \pm 0.62 \log$ CFU. $\mathrm{ml}^{-1} \cdot \mathrm{h}^{-1}\left(\mathrm{R}^{2}=0.99\right)$ and a lag phase $(\lambda)$ of $1.87 \pm 0.77$ hours obtained by fitting using DMFit. These results were slightly different with parameters found by Juneja and Marks (2006) that reported a lag phase of Salmonella spp., in BHIB at $37^{\circ} \mathrm{C}$, of 1.06 hours and an exponential growth rate $(\mu)$ of $0.9 \log \mathrm{CFU} \cdot \mathrm{ml}^{-1} \cdot \mathrm{h}^{-1}$. These differences likely caused by the initial number inoculated, i.e. approximately $10^{1} \mathrm{CFU} / \mathrm{ml}$ in this study and $10^{3} \mathrm{CFU} / \mathrm{ml}$ in Juneja and Marks (2006). Bovill et al. (2000) reported a lag phase of 2 hours when Salmonella grown in Tryptone Soya Broth at $30^{\circ} \mathrm{C}$. Another study, Bovill et al. (2001) showed a lag phase of Salmonella for 0 to 2 hours at $40^{\circ} \mathrm{C}$ by the initial number of $10^{3}$ and $10^{4} \mathrm{CFU} / \mathrm{ml}$.

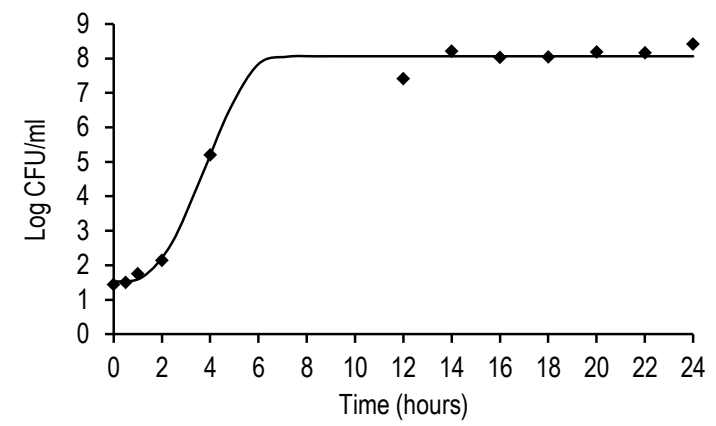

A

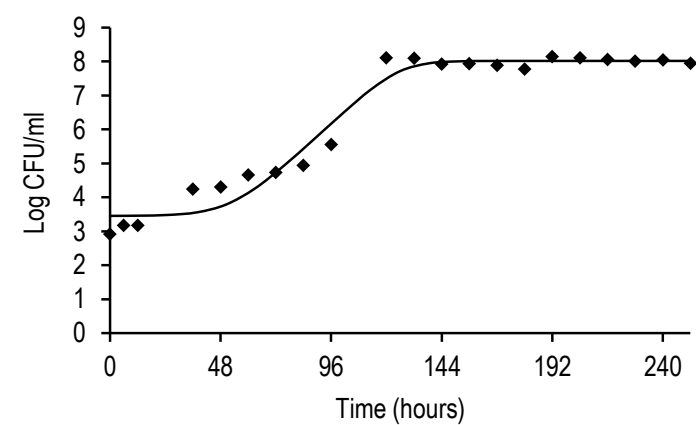

B

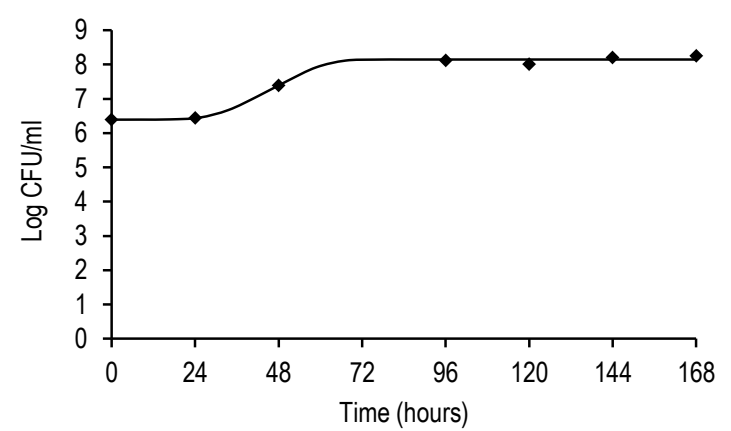

Figure 1. Growth curves of S. Typhimurium ATCC 14028 in BHIB, (A) at optimum temperature $\left(35 \pm 2^{\circ} \mathrm{C}\right)$ for 24 hours, and $(B)$ at low temperature $\left(8 \pm 2^{\circ} \mathrm{C}\right)$ with initial level of $10^{3} \mathrm{CFU} / \mathrm{ml}$ and $(\mathrm{C})$ at low temperature $\left(8 \pm 2^{\circ} \mathrm{C}\right)$ with initial level of $10^{6} \mathrm{CFU} / \mathrm{ml}$, fitted using DMFit software
At low temperature, $S$. Typhimurium grew in BHIB with a growth rate of $0.06 \pm 0.01 \log \mathrm{CFU} \cdot \mathrm{ml}^{-1} \cdot \mathrm{h}^{-1}\left(\mathrm{R}^{2}=0.96\right)$ when the initial level was $10^{3} \mathrm{CFU} / \mathrm{ml}$, and with a growth rate of $0.05 \pm 0.01$ $\log$ CFU.ml-1 $h^{-1} \quad\left(R^{2}=0.98\right)$ when the initial level was $10^{6}$ $\mathrm{CFU} / \mathrm{ml}$. Furthermore, with initial number of $10^{3} \mathrm{CFU} / \mathrm{ml}$, the lag phase of $S$. Typhimurium was $52.73 \pm 10.37$ hours followed by a logarithmic/exponential phase until approximately 132 hours (about 5-6 days). These results was longer than that found by Alvarez-Ordonez et al. (2010) who reported a lag phase about 30 hours with initial level of $10^{4} \mathrm{CFU} / \mathrm{ml}$ at storage temperature of $10^{\circ} \mathrm{C}$. With initial numbers of $10^{6} \mathrm{CFU} / \mathrm{ml}$ the lag phase was obtained for 29.53 hours followed by a log phase until the 60 hours (about 3 days). The length of the lag phase in this study was in contrast to Wan Norhana et al. (2010) which stated that there is no significant growth of the S. Typhimurium ATCC 14028 at chilled temperature for 7 days of storage by the initial number of microorganisms of $10^{6} \mathrm{CFU} / \mathrm{ml}$.

The growth curves of $S$. Typhimurium at low temperature in shrimp and in BHIB, as control, with initial level of approximately $10^{5} \mathrm{CFU} / \mathrm{ml}$ are shown in Figure 2.
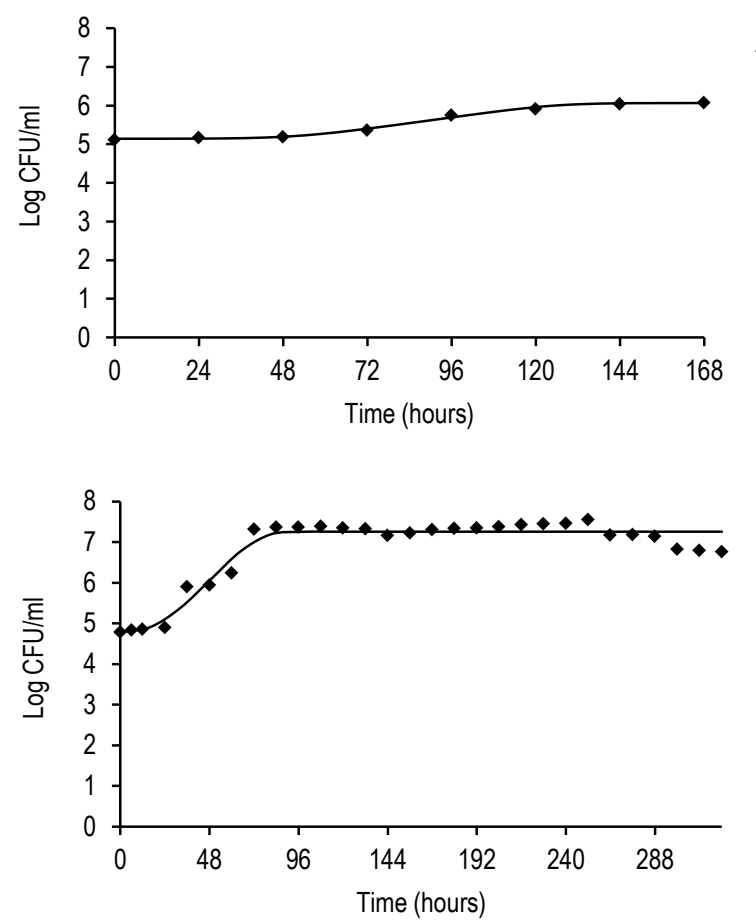

Figure 2. Growth of $S$. Typhimurium at low storage $\left(8 \pm 2^{\circ} \mathrm{C}\right)$ with initial level of $10^{5} \mathrm{CFU} / \mathrm{ml},(\mathrm{A})$ on shrimp and (B) in BHIB media, fitted using DMFit software

The growth rate on shrimps was found as $0.01 \pm 0.002 \log$ CFU. $\mathrm{ml}^{-1} . \mathrm{h}^{-1}\left(\mathrm{R}^{2}=0.99\right)$ with a lag phase up to $51.99 \pm 7.46$ hours (about 2 days), while in BHIB the growth rate was found as $0.05 \pm 0.01$ log CFU.ml-1. $h^{-1} \quad\left(R^{2}=0.93\right)$ and a lag phase approximately $20.20 \pm 10.23$ hours. Different matrix likely caused this difference. Juneja et al. (2007) reported that Salmonella at $37^{\circ} \mathrm{C}$ with the initial number of bacteria of $10^{1} \mathrm{CFU} / \mathrm{ml}$ produced a lag phase in the range of 0 to 1 hour based on the model Gompertz, Logistic or Baranyi on raw chicken. Recapitulation of the exponential growth rates, lag phases and $y_{\max }$, of $S$. 
Typhimurium at different conditions under this study are summarized in Table 1. As indicated in Table 1, Salmonella showed a slow growth on shrimps and BHIB at low temperature. In the same matrix or media and at the same temperature, the lag phase was significantly longer when the initial level was less.

Table 1. Growth parameters of $S$. Typhimurium obtained by fitting using DMFit without addition of sodium metabisulfite

\begin{tabular}{lcccc}
\hline \multicolumn{1}{c}{ Parameter } & \multicolumn{5}{c}{ Data } \\
\hline Medium & BHIB & BHIB & BHIB & Shrimp \\
Storage & $35 \pm 2$ & $8 \pm 2$ & $8 \pm 2$ & $8 \pm 2$ \\
temperature, ${ }^{\circ} \mathrm{C}$ & & & & \\
$\begin{array}{l}\text { Inoculation } \\
\text { level, } \mathrm{CFU} / \mathrm{ml}\end{array}$ & $10^{1}$ & $10^{3}$ & $10^{5}$ & $10^{5}$ \\
$\begin{array}{l}\text { Growth rate }(\mu) \\
\text { log CFU.ml- }\end{array}$ & $1.73 \pm 0.62$ & $0.06 \pm 0.01$ & $0.05 \pm 0.01$ & $0.01 \pm 0.002$ \\
$\begin{array}{l}\text { 1.h-1 } \\
\text { Lag phase }(\lambda), \mathrm{h}\end{array}$ & $1.87 \pm 0.77$ & $52.73 \pm 10.37$ & $20.20 \pm 10.23$ & $51.99 \pm 7.46$ \\
Initial level $\left(\mathrm{y}_{0}\right)$, & 1.51 & 3.45 & 4.79 & 5.14 \\
log CFU/ml & & & & \\
Max level, $\mathrm{y}_{\max }$ & $8.06 \pm 0.11$ & $8.02 \pm 0.13$ & $7.26 \pm 0.05$ & $6.07 \pm 0.03$ \\
$\log \mathrm{CFU} / \mathrm{ml}$ & & & & \\
$\mathrm{R}^{2}$ & 0.99 & 0.96 & 0.93 & 0.99 \\
\hline
\end{tabular}

Antimicrobial activity of sodium metabisulfite by direct contact in suspension

Sodium metabisulfite added in BHIB was able to reduce the number of Salmonella Typhimurium after 24 hours incubation at optimum growth temperature of Salmonella. Figure 3 demonstrated log reduction generated from each concentrations tested. Concentration of $0.4 \%$ sodium metabisulfite reduced the initial level for $1 \log \mathrm{CFU} / \mathrm{ml}$, while $0.5 \%, 0.8 \%, 1 \%, 1.25 \%$ and $1.5 \%$ showed reduction of approximately $3 \log \mathrm{CFU} / \mathrm{ml}$.

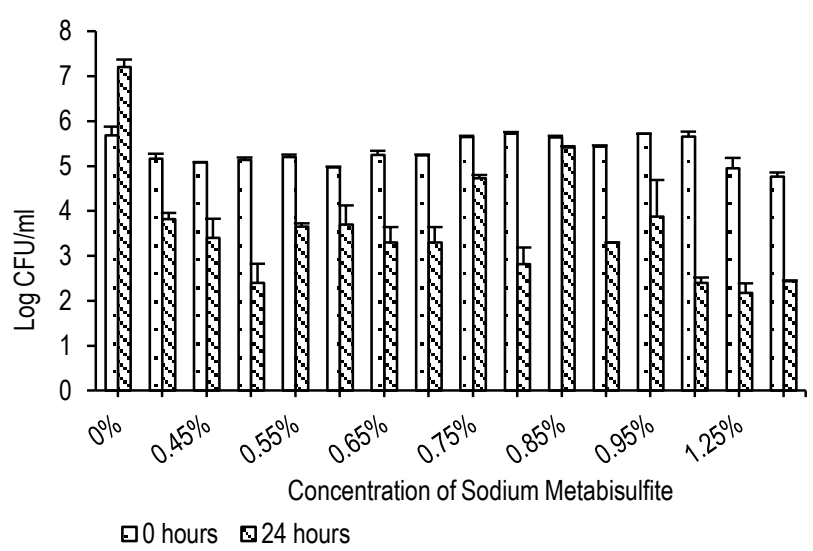

Figure 3. Reduction of $S$. Typhimurium after 24 hours at $35 \pm 2^{\circ} \mathrm{C}$ in $\mathrm{BHIB}$ with addition of sodium metabisulfite

At low temperature, the reduction of $S$. Typhimurium level was also found in the presence of $0.4 \%, 1.25 \%$, and $1.5 \%$ sodium metabisulfite in BHIB, as shown in Figure 4. The concentration of $1.5 \%$ is the highest concentration allowed in Indonesia. Application of sodium metabisulfite with concentration of $0.4 \%$ already resulted in slightly reduction of the numbers of bacteria (approximately $0.5 \log \mathrm{CFU} / \mathrm{ml}$ ) in BHIB during storage at low temperature for 7 days. The effect in reduction of bacteria was not statistically different with that demonstrated by $1.25 \%$ at $a=0.05$. Concentration of $1.5 \%$, however, demonstrated significant difference in reducing bacteria in comparison with $0.4 \%$ and $1.25 \%$. Alvarez-Ordonez et al. (2010) determined the effect of acetic acid, citric, lactic and hydrochloric on $S$. Typhimurium (initial bacteria of $10^{3}$ $\mathrm{CFU} / \mathrm{ml}$ ) at various storage temperatures. The result showed that $S$. Typhimurium did not grow in acidic condition at storage temperature below $10^{\circ} \mathrm{C}$.
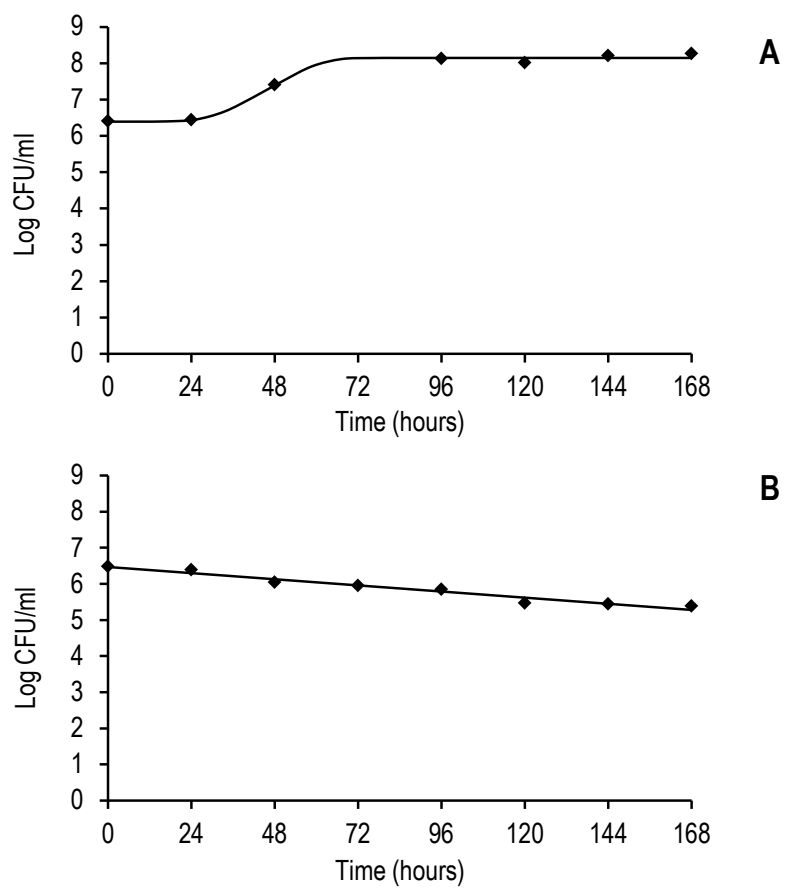

B

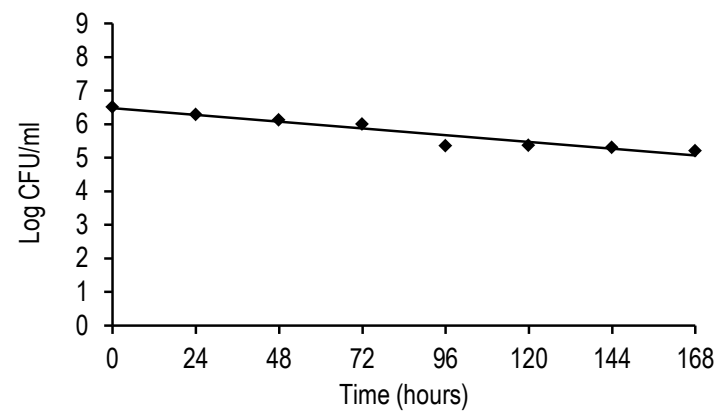

C

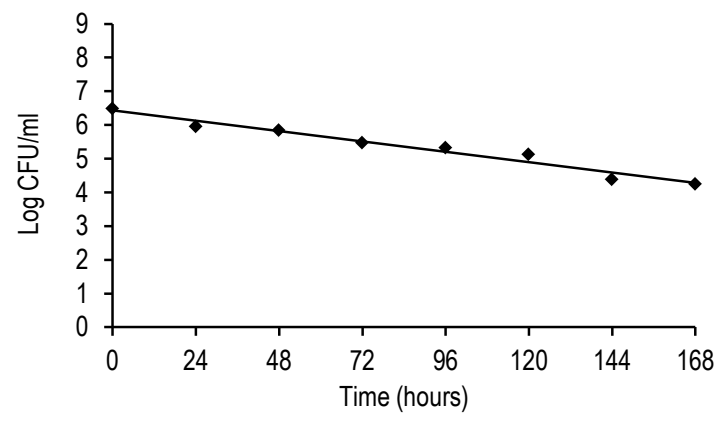

Figure 4. Survival of $S$. Typhimurium in BHIB at $8 \pm 2^{\circ} \mathrm{C}$; (A) without addition of sodium metabisulfite, and addition of sodium metabisulfite: (B) $0.4 \%,(C) 1.25 \%$, and (D) $1.5 \%$, fitted using DMFit software 
Survival of S. Typhimurium on shrimps at low temperature with addition of sodium metabisulfite

Combination of storage at low temperatures with addition of sodium metabisulfite also showed inhibition of the growth of $S$. Typhimurium on raw shrimps as shown at Figure 5.
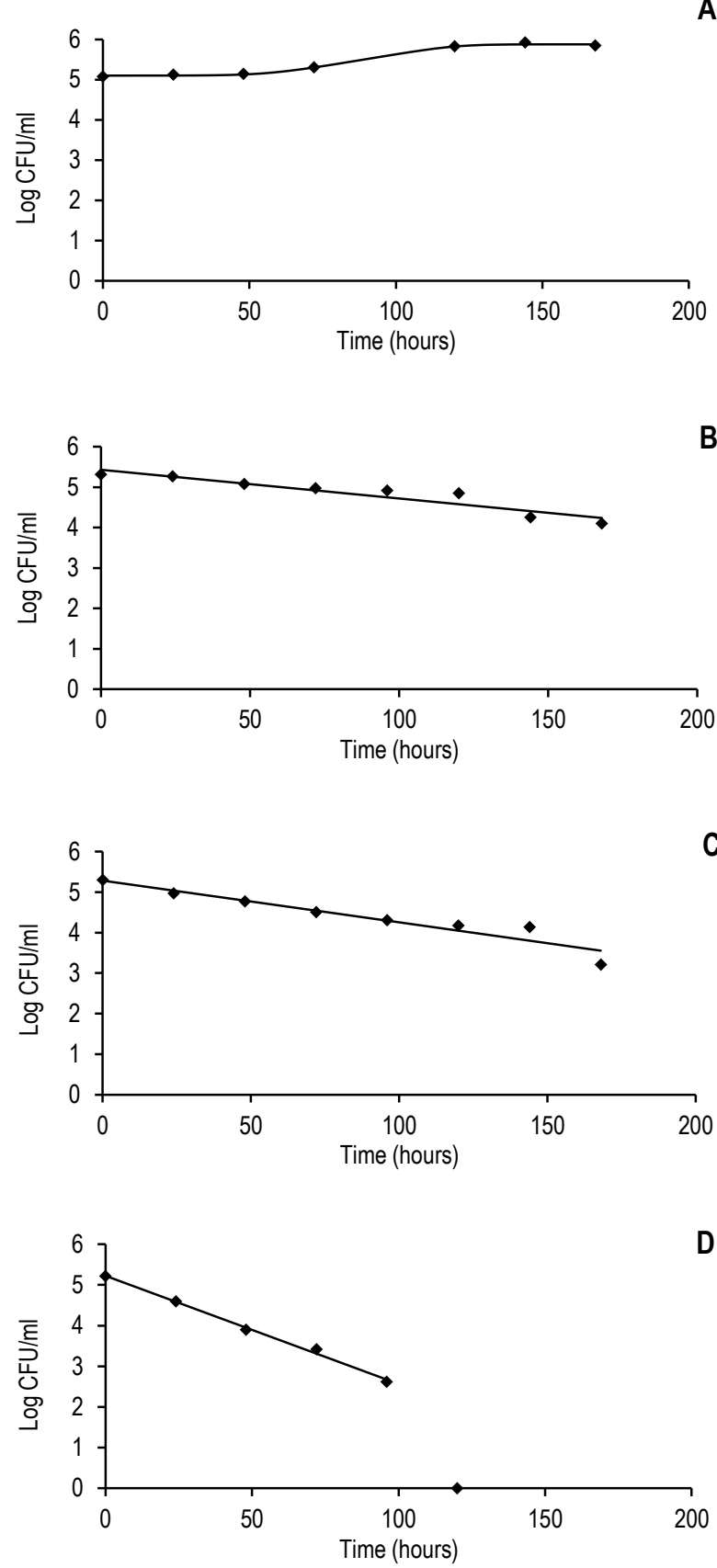

Figure 5. Survival of $S$. Typhimurium on shrimp at low temperature $\left(8+2^{\circ} \mathrm{C}\right)$, (A) without addition of $\mathrm{Na}_{2} \mathrm{~S}_{2} \mathrm{O}_{5}$, and with the addition of sodium metabisulfite (B) $0.4 \%$, (C) $1.25 \%$, and (D) $1.5 \%$, fitted using DMFit software

The concentration of sodium metabisulfite used was able to reduce the number of bacteria during storage at low temperatures $\left(8 \pm 2^{\circ} \mathrm{C}\right)$ i.e. reduction of approximately 1 log
$\mathrm{CFU} / \mathrm{ml}$ by $0.4 \%$ and reduction of $1.6 \log \mathrm{CFU} / \mathrm{ml}$ by $1.25 \%$ after 7 days. Reduction of $2.6 \log \mathrm{CFU} / \mathrm{ml}$ from initial level was demonstrated by addition of $1.5 \%$ after 4 days. The addition of sodium metabisulfite showed significantly difference at $\alpha=0.05$ in reducing the number of bacteria for all concentration. Januario and Dykes (2005) who used sodium metabisulfite $1 \%$ produced a reduction of 4 log units of Vibrio cholerae during cold storage temperature. On the other hand, Norhana et al. (2012) reported that all treatments with antimicrobials (Nisin, EDTA, potassium sorbate, sodium benzoate, or sodium diacetate; alone or in combination) failed to significantly reduce $(a>0.05)$ Salmonella on shrimp surfaces immediately after dipping or throughout the 7 days of storage at $4^{\circ} \mathrm{C}$. The mean number of Salmonella on inoculated shrimps after inoculation was approximately $4.65 \log \mathrm{CFU} / \mathrm{ml}$.

\section{Growth and reduction rates of S. Typhimurium in BHIB and shrimp}

Table 2 summarizes the growth rates or reduction rates (indicated with negative (-) mark) at different conditions. This table also shows the comparison of the $\mu$ values from observations to the $\mu$ values obtained from DMFit software. The data indicated that, when reduction of $S$. Typhimurium was found, as result of addition of sodium metabisulfite, the $\mu$ values calculated using the slope of the reduction line was comparable with that obtained from DMFit. However, when the slow growth of $S$. Typhimurium was found, the $\mu$ values obtained using DMFit were relatively higher than observed $\mu$ values calculated using the slope of the line.

Furthermore, the growth rate $(\mu)$ is highly affected by the growth medium (matrix) and the initial number of microorganisms. As indicated in the Table 2, with the same initial level of $10^{5} \mathrm{CFU} / \mathrm{ml}$, the growth of $S$. Typhimurium at low temperature was found faster in BHIB than on shrimps which have a more complex matrix. The greater the initial number of the bacteria the greater the $\mu$ value generated under the same conditions. The trend of this result is similar as found by Oscar (2007) who reported the growth of S. Typhimurium DT104 from low and high initial density on ground chicken.

Table 2. Comparison of growth or reduction rates $(\mu)$ of $S$. Typhimurium at $8 \pm 2^{\circ} \mathrm{C}$ with different initial levels by observation and fitting using Baranyi model incorporated in DMfit software

\begin{tabular}{lcccc}
\hline $\begin{array}{c}\text { Media, } \\
\text { Temperature }\end{array}$ & $\begin{array}{c}\text { Initial } \\
\text { Level } \\
\text { (cfu/ml) }\end{array}$ & $\begin{array}{c}\mathrm{Na}_{2} \mathrm{~S}_{2} \mathrm{O}_{5} \\
(\%)\end{array}$ & $\begin{array}{c}\mu \text { Observation } \\
\text { (log cfu.ml- } \mathrm{h}^{-1} \text { ) }\end{array}$ & $\begin{array}{c}\mu \text { Baranyi }{ }^{* *} \\
\left.\text { (log cfu.ml- }{ }^{-1} . \mathrm{h}^{-1}\right)\end{array}$ \\
\hline $\mathrm{BHIB}, 35 \pm 2^{\circ} \mathrm{C}$ & $10^{1}$ & 0 & $1.528 \pm 0.820$ & $1.728 \pm 0.616$ \\
$\mathrm{BHIB}, 8 \pm 2^{\circ} \mathrm{C}$ & $10^{3}$ & 0 & $0.056 \pm 0.020$ & $0.063 \pm 0.014$ \\
$\mathrm{BHIB}, 8 \pm 2^{\circ} \mathrm{C}$ & $10^{5}$ & 0 & $0.043 \pm 0.015$ & $0.045 \pm 0.012$ \\
$\mathrm{BHIB}, 8 \pm 2^{\circ} \mathrm{C}$ & $10^{6}$ & 0 & $0.040 \pm 0.095$ & $0.054 \pm 0.090$ \\
$\mathrm{BHIB}, 8 \pm 2^{\circ} \mathrm{C}$ & $10^{6}$ & 0.4 & $-0.007 \pm 0.001$ & $-0.007 \pm 0.0006$ \\
$\mathrm{BHIB}, 8 \pm 2^{\circ} \mathrm{C}$ & $10^{6}$ & 1.25 & $-0.008 \pm 0.001$ & $-0.008 \pm 0.001$ \\
$\mathrm{BHIB}, 8 \pm 2^{\circ} \mathrm{C}$ & $10^{6}$ & 1.5 & $-0.013 \pm 0.001$ & $-0.013 \pm 0.001$ \\
Shrimp, $8 \pm 2^{\circ} \mathrm{C}$ & $10^{5}$ & 0 & $0.008 \pm 0.001$ & $0.013 \pm 0.002$ \\
Shrimp, $8 \pm 2^{\circ} \mathrm{C}$ & $10^{5}$ & 0.4 & $-0.007 \pm 0.001$ & $-0.007 \pm 0.001$ \\
Shrimp, $8 \pm 2^{\circ} \mathrm{C}$ & $10^{5}$ & 1.25 & $-0.012 \pm 0.001$ & $-0.010 \pm 0.001$ \\
Shrimp, $8 \pm 2^{\circ} \mathrm{C}$ & $10^{5}$ & 1.5 & $-0.027 \pm 0.001$ & $-0.026 \pm 0.001$ \\
\hline
\end{tabular}

${ }^{*}$ Calculated from the slope of logarithmic phase or reduction line ** DmFit 


\section{CONCLUSION}

S. Typhimurium demonstrated a slow growth in brain heart infusion broth (BHIB) at low temperature and on raw shrimps during cold storage, indicated by a low value of growth rate ( $<0.1 \log$ CFU. $\mathrm{ml}^{-1} . \mathrm{h}^{-1}$ ) after a long lag phase ( $>20$ hours). Addition of sodium metabisulfite, however, resulted in no growth of $S$. Typhimurium, instead, the reduction of the level of $S$. Typhimurium was occured. Furthermore, the Baranyi model can be used to predict the slow growth of $S$. Typhimurium at low temperature in raw shrimp as well as in BHIB when sodium metabisulfite is absent. However, when sodium metabisulfite is present, at least $0.4 \%$ as indicated in this study, the survival of $S$. Typhimurium can be predicted using a simple linear model.

\section{ACKNOWLEDGEMENT}

This research was partially supported by Directorate General of Higher Education through Competence Grant Scheme.

\section{REFERENCES}

Alvarez-Ordonez A, Ana F, Ana B, Mercedes L. 2010. Acid tolerance in Salmonella Typhimurium induced by culturing in the presence of organic acids at different growth temperatures. Int J Food Microbiol 27: 44-49. DOI: 10.1016/.j.fm.2009.07.015.

Bovill RA, Jan B, Cook N, D'Agostino M, Wilkinson N, Jozsef B. 2000. Predictions of growth for Listeria monocytogenes and Salmonella during fluctuating temperature. Int $\mathrm{J}$ Food Microbiol 59: 157-165.

Bovill RA, Jan B, Jozsef B. 2001. Measurement and predictions of growth for Listeria monocytogenes and Salmonella during fluctuating temperature: II Rapidly changing temperatures. Int J Food Microbiol 67: 131-137. DOI: 10.1016/S01681605(01)00446-9.

Hatha AAM, Maqbool TK, Kumar SS. 2003. Microbial quality of shrimp products of export trade produced from aquacultured shrimp. Int J Food Microbiol 82: 213- 221. DOI: 10.1016/S0168-1605(02)00306-9.
Januario FES, Dykes GA. 2005. Effect of sodium metabisulfite and storage temperature on the survival of Vibrio cholera on prawns (Penaeus monodon). World J Microbiol Biotech 21: 1017-1020. DOI: 10.1007/s11274-004-7654-3.

Juneja VK, Marks HM. 2006. Growth kinetics of Salmonella spp. pre- and post-thermal treatment. Int J Food Microbiol 109: 54-59. DOl: 10.1016/.ijfoodmicro.2006.01.009.

Juneja VK, Martin VM, Lihan H, Vinod G, Jeyamkondan S, Harshavardhan T. 2007. Modelling the effect of temperature on growth of Salmonella in chicken. J Food Microbiol 24: 328-335. DOl: 10.1016/i.fm.2006.08.004.

Martinez-Alvarez O, Lopez-Caballero ME, Gomez-Guille MC, Montero P. 2009. The effect of several cooking treatments on subsequent chilled storage of thawed deepwater pink shrimp (Parapenaeus longirostris) treated with different melanosis-inhibiting formulas. LWT Food Sci Technol 42: 1335-1344. DOI: 10.1016/J.LWT.2009.03.025.

Nirmal NP, Benjakul S. 2011. Inhibition of melanosis formation in Pacific white shrimp by the extract of lead (Leucaena leucocephala) seed. Food Chem 128: 427-432. DOI: 10.1016/j.foodchem.2011.03.048.

Oscar TP. 2007. Predictive models for growth of Salmonella Typhimurium DT104 from low and high initial density on ground chicken with a natural microflora. Food Microbiol 24: 640-651. DOI: 10.1016/j.fm.2006.11.003.

Sant'Ana AS, Franco BDGM, Schaffner DW. 2012. Modeling the growth rate and lag time of different strains of Salmonella enterica and Listeria monocytogenes in ready-to-eat lettuce. Food Microbiol 30: 267-273. DOI: 10.1016/iffm.2011.11.003.

Wan Norhana MN, Poole SE, Deeth HC, Dykes GA. 2010. Prevalence, persistence and control of Salmonella and Listeria in shrimp and shrimp products: A review. Food Control 21: 343-361. DOI: 10.1016/j.foodcont.2009.06.020.

Wan Norhana MN, Poole SE, Deeth HC, Dykes GA. 2012. Effects of nisin, EDTA and salts of organic acids on Listeria monocytogenes, Salmonella and native microflora on fresh vacuum packaged shrimps stored at $4^{\circ} \mathrm{C}$. Food Microbiol 31: 43-50. DOl: 10.1016/j.fm.2012.01.007. 